TURIZAM

Volume 24, Issue 4

149-164 (2020)

ORIGINAL

SCIENTIFIC PAPER

\title{
Role of Foreign Tourist Arrivals (FTAs) from Bangladesh in Indian Tourism Development: A Segment-wise Analysis
}

\author{
Rajaul Karim ${ }^{\mathrm{A}}$ \\ Received: May 2020 | Accepted: July 2020 \\ DOI: $10.5937 /$ turizam24-26520
}

\begin{abstract}
Bangladesh being a neighboring country of India plays a crucial role in bringing millions of tourists every year. Bangladesh is the largest tourist generating market for India in which the India-Bangladesh relation is a key factor for this foreign tourist arrivals(FTAs) and tourism development. The main objective of this paper is to find out the trend of Bangladeshi foreign tourist arrivals in India from 2018 to 2025 with respect to observed values of foreign tourist arrivals during previous years, analysis of segment-wise growth rate of Bangladeshi tourist arrivals according to purpose of travel and to make some policy prescriptions. The research is based on secondary data by applying descriptive statistics considering the published reports of the Indian Government from the Ministry of Tourism. The findings of the present research paper show that the trend and growth rate of FTAs are rising steadily as well as the importance of Bangladeshi tourist arrivals in developing certain tourism segments of India that are lacking behind and have some potential for further expansion. Proper attention to these segments is expected to make a positive contribution towards tourism development in particular and economic development in general of India.
\end{abstract}

Keywords: Foreign Tourist Arrivals (FTAs), Bangladeshi Tourist, Tourism Potentiality, Indian Tourism Development.

\section{Introduction}

Tourism is one of the major contributors to the economy of a country especially for the developing countries like India where making a positive change in the economy is not an easy task. Balaguer and Cantavella-Jorda (2002) revealed in their analysis considering the case of Spain that relationship between economic growth and tourism exists in long run. It is also stated in their study that tourism led growth hypothesis has been supported with arguments. Witt and Turner (2002) has expected high growth rates in the coming years by forecasting inbound tourism from the source markets of China but there can be variations depending on different markets. Hyun

A Department of Tourism \& Hospitality, DSMS College, Kazi Nazrul University, West Bengal, India; rejaulkg@gmail.com 
Kim, Chen and Shawn Jang (2006) showed the reciprocal relation between tourism and economic development considering the case of Taiwan. The World Travel and Tourism Council (WTTC) Economic Impact India Report (2018) clearly states that the contribution of travel and tourism in India has a positive rising trend in its forecast in terms of GDP, Employment, Visitor Exports and Investment. The Annual Report (2017-2018) of the Ministry of Tourism, Government of India has made an overview that tourism has the capacity to create employment of diverse kind as well as plays a crucial role in achieving sustainable growth. International tourist arrival in India has been an important factor for employment generation and foreign exchange earnings. Bangladesh being very close and sharing the longest border with India has been a major source of tourist arrivals for India with 2156557 numbers of arrivals in 2017, having a share of around 21.49 percent out of total 10.04 million tourist arrivals in 2017. Bangladesh has also become India's largest tourist generating market holding the top position among top 15 source markets followed by United States, United Kingdom, Canada, Australia, Malaysia, Sri Lanka, Russian Federation, Germany, France, China, Japan, Singapore, Nepal, Afghanistan as per India Tourism Statistics (2018). It is mainly the International tourist arrival in a country that determines its economic development in regard to travel perspective, as more the foreign tourist arrival the more the contribution directly and indirectly to the economy. In fact Indian tourism industry has gone to new height in recent times. It is the 7 th largest Tourism economy in terms of GDP according to WTTC. Both tourist arrival as well as revenue earned thereof are showing a steep hike in Indian tourism industry. As per WTTC (2018) Travel \& Tourism Economic Impact Report of India, the total contribution of this sector in 2017 was INR 15,239.6bn (USD 234.obn) which is 9.4\% of GDP and is expected to rise by $9.9 \%$ in 2028 . The industry generated about $8.0 \%$ of total employment $(41,622,500)$ jobs in 2017 and is expected to rise by $8.4 \%$ in 2028 . In 2017 visitors export contributed about INR 1,777.1bn (USD 27.3bn), 5.8\% of total exports and is expected to grow $5.1 \%$ in 2028 . As a whole, investment in Travel \& Tourism in 2017 was INR 2,706.1 billion, 6.3\% of total investment and is expected to grow 6.1\% of total investment in 2028. It is worth saying after looking the various reports that tourism industry has immense potentiality in creating an impact on GDP, employment, investment and visitors' exports but all these potentialities is observed when there is a rising growth as well as stable tourist inflow in a destination. Without tourist inflow in a destination the travel industry and other allied service industries related to tourism is useless. But the fact of quality and high spending tourists cannot be overlooked. It is the foreign tourists that contributes to foreign exchange earnings and has high spending capacity. Earnings from Foreign Exchange (FEEs) in 2017 accounted for INR 177874 core with a percentage change of 15.4\% over previous year as per data provided on Open Government Data (OGD, 2018) Platform, Government of India.

This study was conducted to identify the role of Bangladeshi tourists' arrival in the growth process of Indian tourism. Further their segment-wise contribution in terms of arrival to understand the stability of inbound tourists for various purposes which may favorably affect the tourism of India, has also been considered.

\section{Need for the Study}

Bangladesh being the top source market for India since 2016 plays a crucial role in developing the Indian tourism industry in particular and Indian economy in general. The tourist arrivals directly and indirectly affects employment generation, hotel room occupancies, foreign exchange earnings, usages of different mode of transport facilities and medical facilities. Tourists from Bang- 
ladesh form a large chunk of total tourists to India. During 2017, the percentage share of tourists from Bangladesh was around 21.49\% out of total foreign tourist arrivals. Needless to say that this high percentage share of tourists plays a vital role in Indian economy. Data from a study conducted by Indian Institute of Tourism and Travel Management (IITTM) and submitted to Ministry of Tourism, Government of India regarding "Study on Visit of Nationals of Bangladesh to India" (2018) also show that these tourists spend an average of 21223 BDT which is equivalent to INR 16978 per tourist, which is a considerable amount of expenditure on Indian goods and services. This might have a favorable impact on the economic growth of India.

Tourists from Bangladesh mainly come to Kolkata or use it as transit point. However, a part of them goes to different pilgrimage destinations like Ajmer, Mumbai and Delhi etc. Another part goes to places in southern India like Bangalore, Hyderabad, Chennai and Vellore etc for medical purposes. So, such arrival of tourists must have some impact on the Indian economy as a whole. However, it may be admitted that the most important impact will be on the economy of West Bengal as a sizeable part of Bangladeshi tourist visits Kolkata in particular for treatment purpose as well as for the purpose of leisure or holiday in Eastern India. Thus the number of tourist arrivals from Bangladesh is an important factor for Indian Tourism having all India as well as regional impacts.

\section{Literature Review}

Foreign tourist arrivals play a vital role for the economic development of a country and it is such a kind of import which makes the economy of a country strong. Aliqah and Al-rfou (2010) highlighted in their study the impact of tourism sector on the economy of Jordan. They also found that the tourism sector is responsible for a significant growth in tourist arrivals along with infrastructural development, legislation, institutional framework and revenue generation. $\mathrm{Du}$, Lew and $\mathrm{Ng}$ (2014) in their study showed that international tourism and growth have a significant association when standard income factors were not taken into account. Rout, Mishra and Pradhan (2016) pointed out the role of the Government in tourism development through trend analysis on Indian perspective. Ekanayake and Long (2012) investigated the relationship between tourism development and economic growth using Granger causality test considering annual data. The result of their study suggested that in developing countries government should focus on economic policies in favour of tourism for economic growth. Cárdenas-García, Sánchez-Rivero and Pulido-Fernández (2013) examined in their study regarding relationship of tourism activity and economic growth by using structural equation modeling (SEM). The result of their study indicated that the relationship occurs more on the developed countries but throws a question about the least developed countries and developing countries. Sinclair (1998) has made an extensive survey of literature regarding tourism and economic development, and argued the problem of the use of environmental recourses which stem the failure in the market considering the methods for increasing, sustainably and the return. As per a recent study on Visit of National of Bangladesh to India (2019) people from Bangladesh are travelling extensively especially in the South Asian regions like India, Thailand, Malaysia and Singapore. The reason behind this travel trend is due to rising per capita income, best medical facilities in the neighboring countries as well as the role of budget carriers operating in Bangladesh. The percentage of FTAs from Bangladesh has increased at an increasing rate with a share of $10.92 \%$ out of total tourist arrival from Bangladesh in 2014. Since then it has increased to $14.13 \%$, $15.68 \%$ and $21.49 \%$ in 2015,2016 , and 2017 respectively. Ohlan (2017) has shown in his study that 
inbound tourism contributes for the economic growth of India in both long-run and shortrun. In the context of policy recommendations he suggested the policy-makers for encouragement of inbound tourism considering the investment goals made by the Government of India in the tourism industry for long-run economic growth. Bulgan, Maden and Yildirim (2019) made an empirical study on the effects of tourism sector on economic growth of Turkey and found a positive relationship between the variables studied upon. They found that an increase in income through tourism also contributes to per capita income and shows significant impact on Turkish economy. They highlighted the importance to support this sector due to its positive effect on macro variables. Lee and Chang (2007) applied a new type of heterogeneous panel co integration technique to investigate the long-run relation between tourism development and economic growth of OECD as well as non-OECD countries. Results indicated that development of tourism has more impact in non-OECD countries as compared to OECD countries in regard to GDP and considering the variable tourism receipts, the greater impact is in Sub-Saharan African countries. In the long-run the panel causality test showed unidirectional relation between tourism development and economic development in OECD countries as compared to non-OECD countries which showed bidirectional relationships but in Asia with a weak relationship. Cortes-Jimenez and Pulina (2010) made an empirical investigation on the tourism sector of Spanish and Italian economies. Their study is demand based using integration, co integration and multivariate Granger causality tests which showed the important role of incoming tourists for both the countries' economy. Zuruba, Ionescua and Constantina (2015) discussed the correlation between sustainable development and tourism as well as ways to measure tourism development. In their study they made a comparison taking three emergent markets from European Union with Romania. The results revealed that most of the developed economies consider tourism as a primary industry for the growth of the economy.

\section{Methodology}

\section{Research Type}

Quantitative Research Methodology has been applied for the study as the analysis is purely based on secondary data. This research study has three sections. The first section deals with the estimation and forecast of trend values of Bangladeshi FTAs to India in order to understand the growing trend. The second section deals with the analysis of growth rate of FTAs according to purpose of travel. The third section deals with the interpretation of the results based on the analysis.

\section{Data Source}

The data for the research is collected from secondary sources which include seventeen years of data. Basically India Tourism Statistics and Annual Reports data are taken for the research obtained from the publications of Ministry of Tourism, Government of India. Besides, data regarding tourism are also obtained from Open Government Data (OGD) Platform, Ministry of Statistics \& Programme Implementation; Government of India websites as well as various Journals related to the study. Data for some years regarding categories of Bangladeshi foreign tourist arrivals were missing from the published government reports so those areas are not considered for the study. 


\section{Representation of Data}

Both Linear and Non-Liner Trend Lines are plotted in time series data against the observed values of Foreign Tourist Arrivals (FTAs) for the estimation and analysis. Data regarding purpose of visit used to be collected earlier through disembarkation cards since 2009. But from 2014 this system of recording data was discontinued and FTAs according to Visa Type was taken into consideration instead of FTAs according to purpose of visit, both of which are very similar. The purpose of visit from the year 2009 to 2014 mainly were - Business, Leisure/Holidays, Medical, Indian Diaspora/VFR and Others but from 2014 to 2017 onwards according to Visa type are - Tourist Visa, Overseas Citizen of India (OCI), Business Visa, Medical Visa, Student Visa and Others. Among them five (5) purposes of visit as variables are considered for the research. They are - Business, Leisure/Holidays, Medical, Indian Diaspora/Visiting Friends \& Relatives (VFR) and others.

\section{Interpretation of Data}

Statistical Package for Social Science (SPSS) version 25 is used for the analysis and interpretation. The statistical tools used for the study are Mean, Standard Deviation, Coefficient of Variation and R2. Application of the coefficient of determination, $\mathrm{R}_{2}$ is done to determine the degree of association between dependent and independent variables.

\section{Results}

\section{Foreign Tourist Arrivals (FTAs) from Bangladesh to India}

The foreign tourist arrivals from Bangladesh in numbers has been shown in the Table.1 and plotted in Figure.1 in order to understand the actual scenario of the trend.

Table 1. Bangladeshi Tourists Arrival (2001-2017)

\begin{tabular}{|r|r|}
\hline Year & FTAs (Numbers) \\
\hline 2001 & 431312 \\
\hline 2002 & 435867 \\
\hline 2003 & 454611 \\
\hline 2004 & 477446 \\
\hline 2005 & 456371 \\
\hline 2006 & 484401 \\
\hline 2007 & 480240 \\
\hline 2008 & 541884 \\
\hline
\end{tabular}

\begin{tabular}{|r|r|}
\hline Year & FTAs (Numbers) \\
\hline 2009 & 468899 \\
\hline 2010 & 431962 \\
\hline 2011 & 463543 \\
\hline 2012 & 487397 \\
\hline 2013 & 524923 \\
\hline 2014 & 942562 \\
\hline 2015 & 1133879 \\
\hline 2016 & 1380409 \\
\hline 2017 & 2156557 \\
\hline
\end{tabular}

The column chart Figure.1 represents that FTAs from Bangladesh since 2001 has been rising steadily and that is why Trend Values need to be found out to determine the future prediction. The Trend values of eight years is being found out from 2018 to 2025 by applying Least Square Method (OLS) to understand whether the trend is rising or falling. 


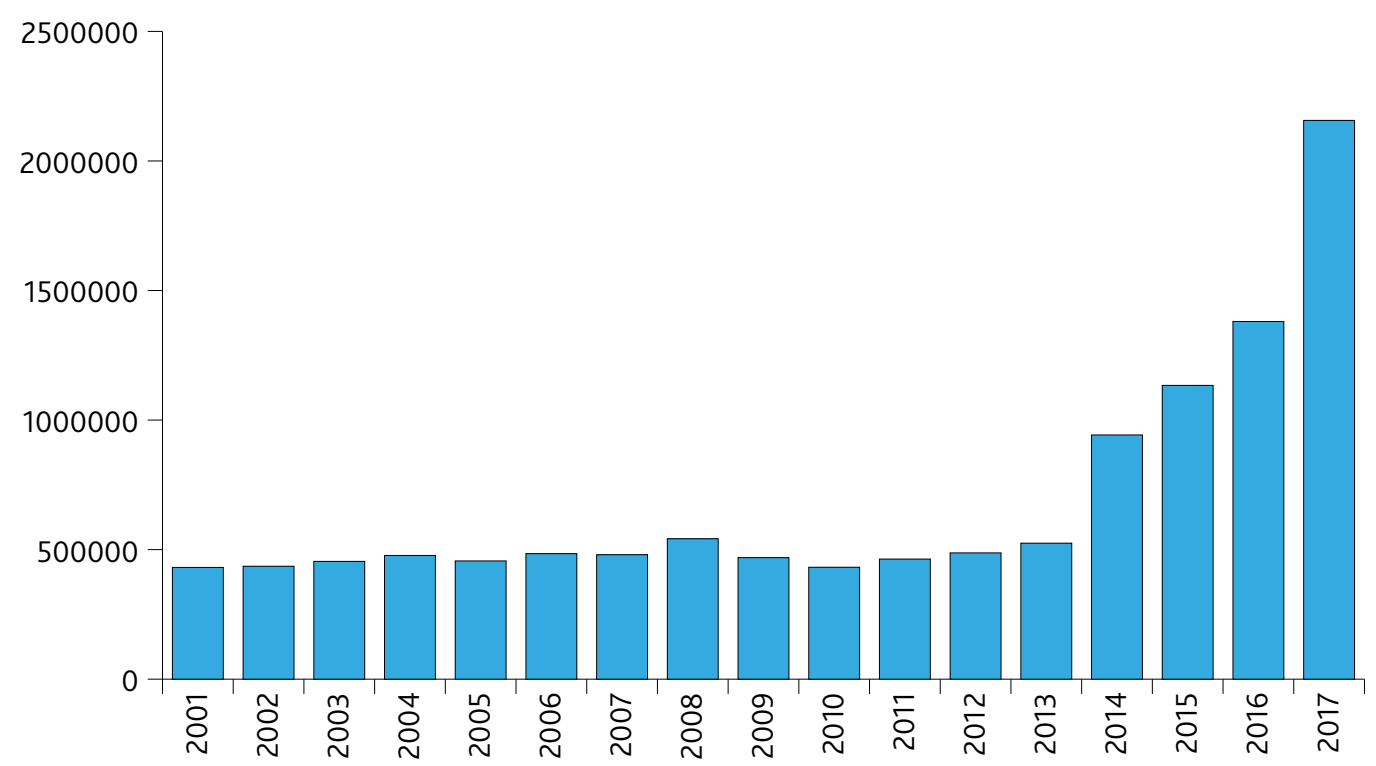

Figure 1. FTAs in India from Bangladesh (2001-2017)

Source: India Tourism Statistics, Ministry of Tourism, Govt. of India

Trend Line (Linear) on FTAs from Bangladesh- Finding the Trend Value of Foreign Tourist Arrivals from Bangladesh by Applying Least Square Method

Let the equation of Trend Line be $(\boldsymbol{y}=\boldsymbol{a}+\boldsymbol{b} \boldsymbol{t})$, where ' $\boldsymbol{a}$ ' and ' $b$ ' are two parameters. The values of $a$ and $b$ can be determined with the help of two normal equations:

$\sum y=n a+b \sum t$

$\sum y=a \sum t+b \sum t^{2}$

( $n=$ number of years)

Using the data from Table.8, $\mathbf{a}=\mathbf{6 9 1 3 0 9 . 5 8}$ and $\mathbf{b}=\mathbf{6 6 0 6 5 . 7 4}$ are obtained. Now putting the values of ' $a$ ' and ' $b$ ' in Trend Equation:

$y=a+b t$

$=691309.58+66065.74 \mathrm{t}=162783.66$

For the year 2001, $y=162783.66$. The trend values for the years 2001-2017 have been calculated and shown in Table.2. 
Table 2. Linear Trend Values (2001-2017)

\begin{tabular}{|r|r|}
\hline Year & \multicolumn{1}{|c|}{ Trend Value } \\
\hline 2001 & 162783.66 \\
\hline 2002 & 228849.40 \\
\hline 2003 & 294915.14 \\
\hline 2004 & 360980.88 \\
\hline 2005 & 427046.62 \\
\hline 2006 & 493112.36 \\
\hline 2007 & 559178.10 \\
\hline 2008 & 625243.84 \\
\hline
\end{tabular}

\begin{tabular}{|c|r|}
\hline Year & Trend Value \\
\hline 2009 & 691309.58 \\
\hline 2010 & 757375.32 \\
\hline 2011 & 823441.06 \\
\hline 2012 & 889506.80 \\
\hline 2013 & 955572.54 \\
\hline 2014 & 1021638.28 \\
\hline 2015 & 1087704.02 \\
\hline 2016 & 1153769.77 \\
\hline 2017 & 1219835.51 \\
\hline
\end{tabular}

(Base Year=2009); Source: Author's Own Calculation

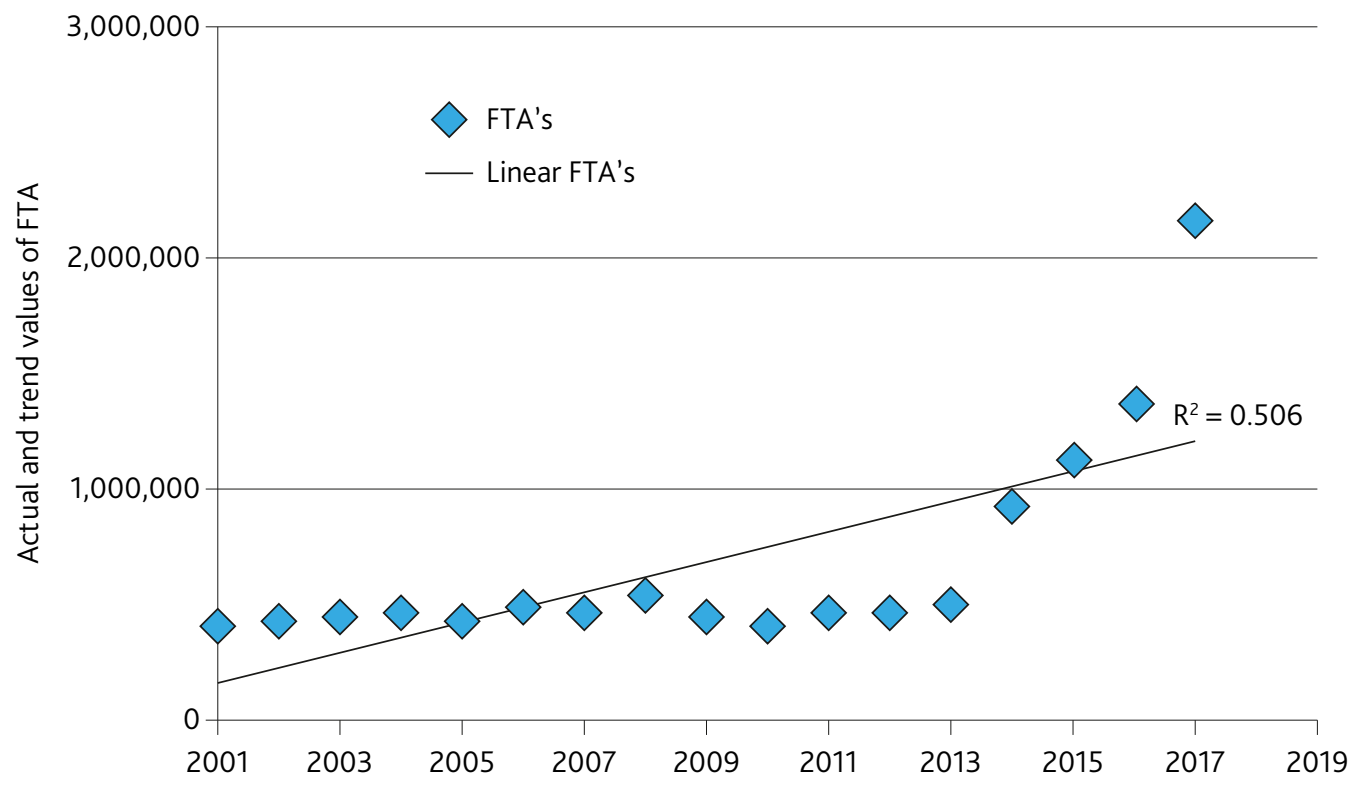

Figure 2. Diagram Showing Linear Trend Lines on FTAs from Bangladesh (2001-2017)

From the above Trend line graph Figure 2 it is found that the trend values from 2001 to 2017 are rising every year touching a value of $\mathbf{1 2 1 9 8 3 5 . 5 1}$ in 2017. The value is quite good and shows the rising trend of foreign tourists from Bangladesh to India in the coming years which may contribute to the development of Indian economy. However the estimation has some major limitations. The limitations are - the value of linear correlation in this case is $\mathbf{R}^{2}=\mathbf{0 . 5 0 6}$, which shows only a moderate correlation between year and trend values of tourists and the observed data in Figure 1 shows that the values of FTAs till 2011 are on the average constant but after that the values of FTAs have steadily increased and that is why a Linear Trend Line doesn't represent to the observed data of FTAs in Figure 2. Hence, a quadratic equation (Eq.7) is a better fit in the data, rather than a liner equation (Eq.3). 
Non-Liner (Quadratic) Trend Line on FTAs from Bangladesh- Finding the Trend Value of Foreign Tourist Arrivals from Bangladesh by Applying Quadratic Equation

Let the equation of Trend Line be $\left(\boldsymbol{y}=\boldsymbol{a}+\boldsymbol{b} \boldsymbol{t}+\boldsymbol{c} \boldsymbol{t}^{2}\right)$, where ' $a$ ', ' $b$ ' and ' $c$ ' are the three parameters. The values of $a, b$ and $c$ can be determined with the help of three normal equations:

$$
\begin{aligned}
& \sum y=n a+b \sum t+c \sum t^{2} \\
& \sum y t=a \sum t+b \sum t^{2}+c \sum t^{3} \\
& \sum t^{2} y=a \sum t^{2}+b \sum t^{3}+c \sum t^{4}
\end{aligned}
$$

$(\mathrm{n}=$ number of years)

Using the data from Table 9, $\mathbf{a}=\mathbf{3 9 8 8 9 9 . 3 4}, \mathbf{b}=\mathbf{6 6 0 6 5 . 7 4}$ and $\mathbf{c}=\mathbf{1 2 1 8 3 . 7 6}$ are obtained.

Now putting the values of 'a', 'b' and 'c' in Trend Equation:

$y=a+b t+c t^{2}$

$$
=398899.34+66065.74 \mathrm{t}+12183.76 \mathrm{t}^{2}=650134.06
$$

For the year 2001, the trend value is, $y=650134.06$. The trend values for the years 2001-2025 are calculated taking the estimated quadratic equation and have been presented them in Table 3 .

Table 3. Non-Linear Trend Values (2001-2025)

\begin{tabular}{|r|r|}
\hline Years & \multicolumn{1}{|c|}{ Trend value } \\
\hline 2001 & 650134.06 \\
\hline 2002 & 533443.40 \\
\hline 2003 & 441120.26 \\
\hline 2004 & 373164.64 \\
\hline 2005 & 329576.54 \\
\hline 2006 & 310355.96 \\
\hline 2007 & 315502.90 \\
\hline 2008 & 345017.36 \\
\hline 2009 & 398899.34 \\
\hline 2010 & 477148.84 \\
\hline 2011 & 579765.86 \\
\hline 2012 & 706750.40 \\
\hline
\end{tabular}

\begin{tabular}{|r|r|}
\hline Years & \multicolumn{1}{|c|}{ Trend value } \\
\hline 2013 & 858102.46 \\
\hline 2014 & 1033822.04 \\
\hline 2015 & 1233909.14 \\
\hline 2016 & 1458363.76 \\
\hline 2017 & 1707185.90 \\
\hline 2018 & 1980375.56 \\
\hline 2019 & 2277932.74 \\
\hline 2020 & 2599857.44 \\
\hline 2021 & 2946149.66 \\
\hline 2022 & 3316809.40 \\
\hline 2023 & 3711836.66 \\
\hline 2024 & 4131231.44 \\
\hline 2025 & 4574993.74 \\
\hline
\end{tabular}

(Base Year=2009); Source: Author's Own Calculation

These estimated values are plotted in terms of a line diagram in Figure 3. The curve has also been plotted using the estimated quadratic equation. 


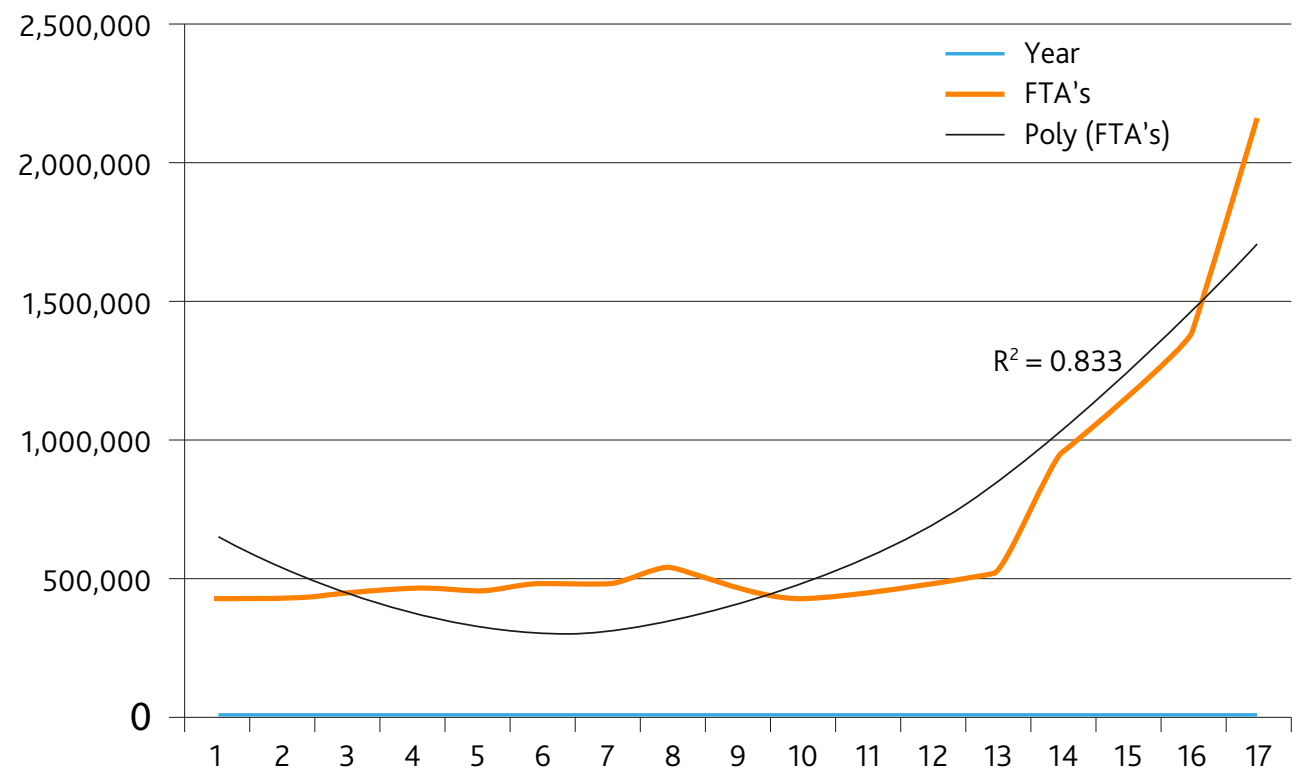

Figure 3. Line Diagram and Non-Linear Quadratic Equation Function Showing Estimated Values of FTAs during (2001-2017)

The value of non-linear correlation in this case, Figure 3 is $\mathbf{R}^{2}=\mathbf{o . 8 3 3}$, which shows a high degree of correlation between year and trend values of tourists than the linear trend line in Figure 2.

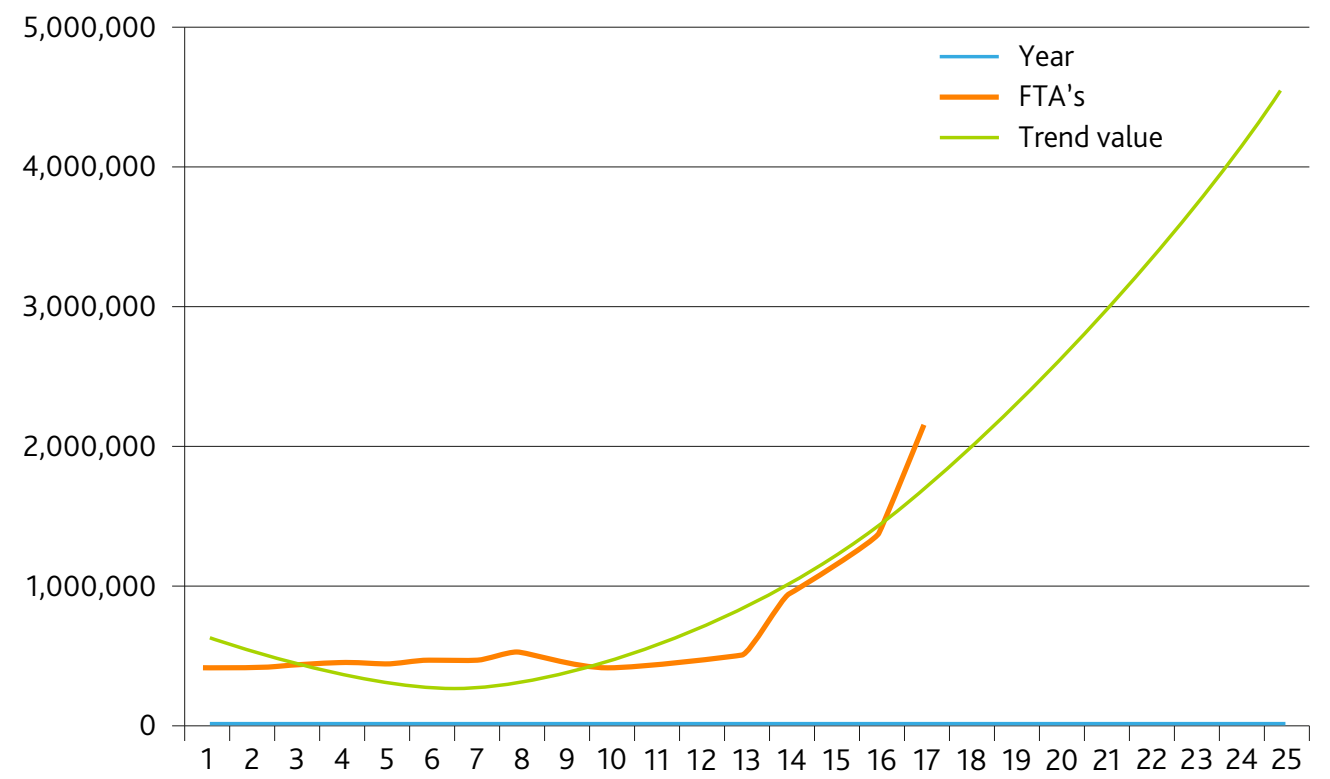

Figure 4. Figure Showing Expected Trend Values of FTAs during (2018-2025) 


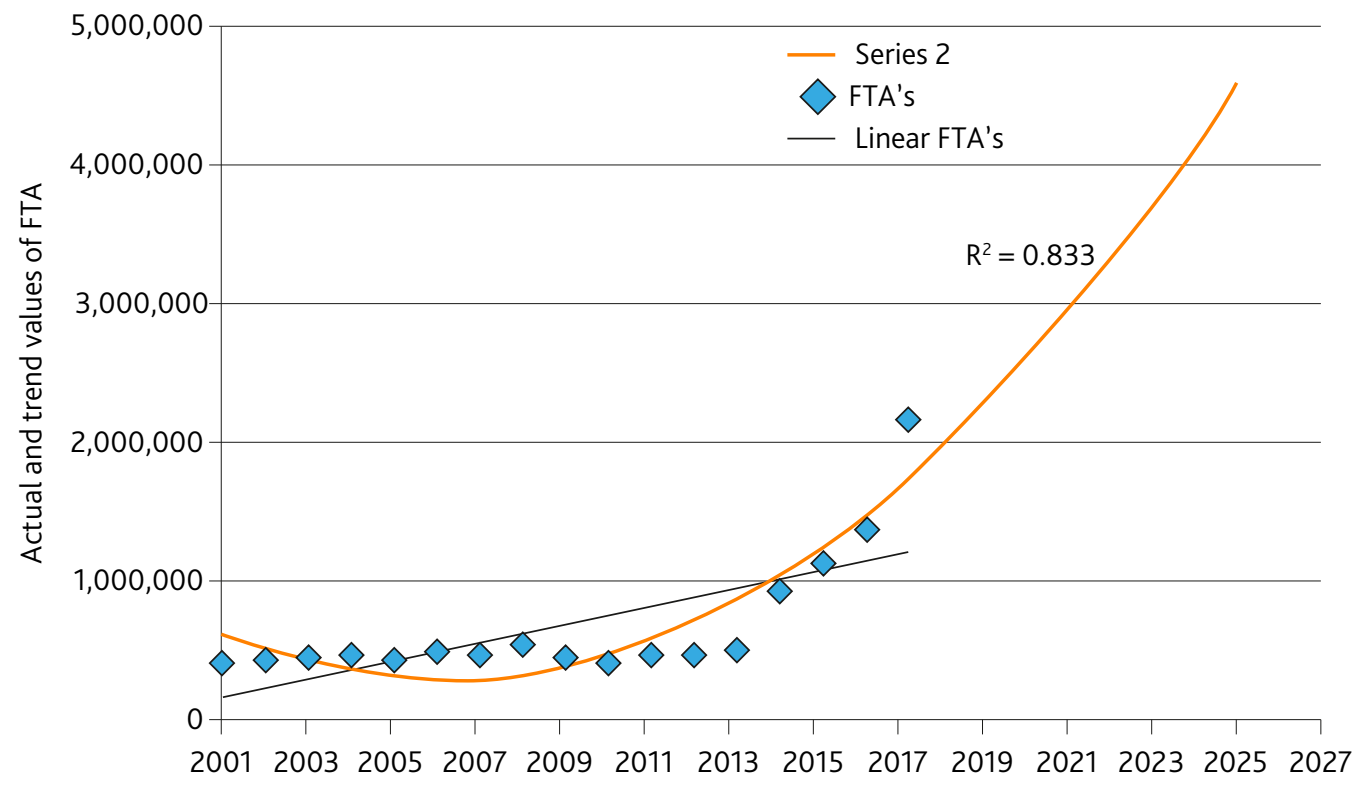

Figure 5. Figure Showing a Comparison between Linear and Non-Linear (Quadratic) Trend Lines on FTAs from (2001-2025)

The diagram above showing the comparison of linear and non-linear trend lines Figure 5 clearly demonstrates the fact that a non-linear trend line (Series 2) through quadratic equation is a better fit \& giving us better results as compared to liner trend line (Linear FTAs) for trend and predicted values for the future years. The future trend values from 2018 to 2025 are showing a rising trend which is plotted in the diagram Figure 4 and the value of $\mathbf{R}^{\mathbf{2}}=\mathbf{0 . 8 3 3}$ in non- linear trend line Figure 3 has a high correlation compared to linear trend line Figure 2. Given that $\mathrm{R}^{2}=\mathrm{ESS} / \mathrm{TSS}$, where ESS is the explained sum of squares and TSS is the total sum of squares, the quite high value of $R^{2}$ (o.833) indicates that there is a close relation between the observed values and the predicted values.

This rising trend has a possibility of positive effect on the Indian economy through tourism in the future years but the economic development through tourism is based on segment wise contribution of inflow of foreign tourists from Bangladesh. Broadly these segments are mainly classified into five as per Ministry of Tourism, Government of India (Business, Leisure, Medical, Indian Diaspora/VFR and Others). The decomposition of FTAs according to purpose needs to be shown to find out which segment has the highest and which segment has the lowest growth rates. The results of the decomposition may show us the way to suggest certain policy prescriptions for development of those segments which are lacking in growth rate in future years.

\section{Growth Rate of different Categories of FTAs from Bangladesh}

In this section the growth rates of foreign tourist arrivals from Bangladesh to India on the basis of their purpose of visit has been examined. The data for the period from 2010 to 2017, as collected from the published India Tourism Statistics Reports, Market Research Division, Ministry of Tourism, Government of India have been taken. The main problem in this exercise is the non-availability of some data corresponding to various categories of foreign tourists. 
Table 4. Bangladeshi Tourists of Different Categories (2010-2017)

\begin{tabular}{|c|c|c|c|c|c|c|}
\hline Year & $\begin{array}{c}\text { Total FTAs from } \\
\text { Bangladesh (Numbers) }\end{array}$ & $\begin{array}{c}\text { Business/ } \\
\text { Business Visa (\%) }\end{array}$ & $\begin{array}{l}\text { Leisure/ Holiday/ } \\
\text { Tourist Visa (\%) }\end{array}$ & $\begin{array}{c}\text { Medical/ } \\
\text { Medical Visa (\%) }\end{array}$ & $\begin{array}{c}\text { Indian Diaspora/ } \\
\text { VFR (\%) }\end{array}$ & $\begin{array}{l}\text { Others } \\
(\%)\end{array}$ \\
\hline 2010 & 431962 & 5.4 & 11.4 & 8.3 & 19.4 & 55.4 \\
\hline 2011 & 463543 & 4.4 & 25.4 & 7.5 & 23.8 & 39.0 \\
\hline 2012 & 487397 & 6.3 & 38.4 & 7.7 & 27.6 & 20.0 \\
\hline 2013 & 524923 & 5.5 & 25.5 & 6.8 & 27.5 & 33.9 \\
\hline 2014 & 942562 & 3.6 & 88.0 & 7.1 & N.A* & 0.7 \\
\hline 2015 & 1133879 & N.A* & N.A* & N.A* & N.A* & N.A* \\
\hline 2016 & 1380409 & 6.27 & 78.58 & 13.14 & 1.03 & 0.98 \\
\hline 2017 & 2156557 & 4.66 & 83.70 & 10.28 & 0.67 & 0.66 \\
\hline
\end{tabular}

(VFR: Visiting Friends \& Relatives); ( ${ }^{*}$ N.A: Not Available)

Source: India Tourism Statistics Reports, Ministry of Tourism, Govt. of India

Data regarding Foreign Tourist Arrivals (FTAs) is converted into actual numbers from corresponding percentages. Then the growth rate of tourists of different categories immediately after the relevant category has been calculated.

Table 5. Growth Rate of Bangladeshi Tourists of Different Categories (2010-2017)

\begin{tabular}{|r|r|r|r|r|}
\hline Year & Business & $\begin{array}{c}\text { Business Growth } \\
\text { Rate }\end{array}$ & Leisure/ Holiday & \multicolumn{1}{c|}{$\begin{array}{c}\text { Leisure/ Holiday } \\
\text { Growth Rate }\end{array}$} \\
\hline 2010 & 23325.948 & --- & 49243.668 & -- \\
\hline 2011 & 20395.892 & -12.56135871 & 117739.922 & 139.0965718 \\
\hline 2012 & 30706.011 & 50.5499784 & 187160.448 & 58.96090707 \\
\hline 2013 & 28870.765 & -5.976829748 & 133855.365 & -28.48095501 \\
\hline 2014 & 33932.232 & 17.53146132 & 829454.56 & 519.6647852 \\
\hline 2015 & N.A* & N.A* & N.A* & N.A* \\
\hline 2016 & 86551.644 & 155.0720633 & 1084725.392 & 30.77574644 \\
\hline 2017 & 100495.556 & 16.11051068 & 1805038.209 & 66.40508482 \\
\hline
\end{tabular}

( ${ }^{*}$. A: Not Available); Source: Author's own Calculation

The table continued...

\begin{tabular}{|r|r|r|r|r|r|r|}
\hline Year & \multicolumn{1}{|c|}{ Medical } & $\begin{array}{c}\text { Medical } \\
\text { Growth Rate }\end{array}$ & $\begin{array}{c}\text { Indian } \\
\text { Diaspora/VFR }\end{array}$ & $\begin{array}{c}\text { Indian Diaspora/ } \\
\text { VFR Growth Rate }\end{array}$ & \multicolumn{1}{|c|}{ Others } & $\begin{array}{c}\text { Others } \\
\text { Growth Rate }\end{array}$ \\
\hline 2010 & 35852.846 & --- & 83800.628 & --- & 239306.948 & --- \\
\hline 2011 & 34765.725 & -3.032174907 & 110323.234 & 31.64965064 & 180781.77 & -24.45611316 \\
\hline 2012 & 37529.569 & 7.949910436 & 134521.572 & 21.93403613 & 97479.4 & -46.07896582 \\
\hline 2013 & 35694.764 & -4.888958357 & 144353.825 & 7.309053005 & 177948.897 & 82.55025882 \\
\hline 2014 & 66921.902 & 87.48380575 & N.A* & N.A* & 6597.934 & -96.29223102 \\
\hline 2015 & N.A* & N.A* & N.A* & N.A* & N.A* & N.A* \\
\hline 2016 & 181385.742 & 171.0409256 & 14218.212 & -90.15044271 & 13528.0082 & 105.0340031 \\
\hline 2017 & 221694.059 & 22.22242852 & 14448.931 & 1.622701846 & 14233.2762 & 5.213391281 \\
\hline
\end{tabular}

(*N.A: Not Available); Source: Author's own Calculation 
To have a quick look or to get some gross idea regarding the growth rate, the mean growth rate of tourists of each category has been calculated. Table 6 shows the mean growth rate and the values are plotted in Figure 6.

Table 6. Purpose-wise Mean Growth Rate (2010-2017)

\begin{tabular}{|c|r|}
\hline Variables & Mean Growth Rate \\
\hline Business & 36.78763755 \\
\hline Leisure/Holiday & 131.0703567 \\
\hline Medical & 46.7959895 \\
\hline Indian Diaspora/VFR & -5.527000217 \\
\hline Others & 4.328390529 \\
\hline
\end{tabular}

Source: Author's own Calculation

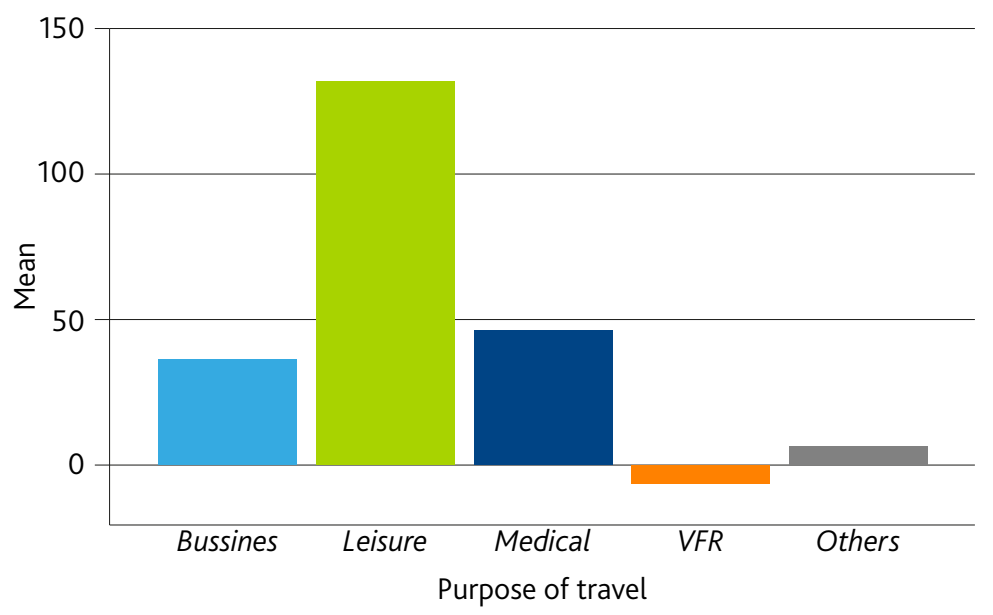

Figure 6. Growth Rates According to Purpose (2010-2017)

Using the data from Table 5, the mean, standard deviation and coefficient of variation are calculated in Table 7 .

Table 7. Descriptive Statistics

\begin{tabular}{|c|c|r|r|r|r|r|}
\hline Variables & N & Minimum & Maximum & \multicolumn{1}{c|}{ Mean } & \multicolumn{1}{c|}{ Std. Deviation } & C.V \\
\hline Business & 7 & 20395.89 & 100495.56 & 46325.4355 & 32802.66996 & 0.708091993 \\
\hline Leisure & 7 & 49243.67 & 1805038.21 & 601031.0806 & 666252.25209 & 1.108515472 \\
\hline Medical & 7 & 34765.73 & 221694.06 & 87692.0869 & 79451.17668 & 0.906024472 \\
\hline VFR & 6 & 14218.21 & 144353.83 & 83611.0673 & 57608.86586 & 0.689010053 \\
\hline Others & 7 & 6597.93 & 239306.95 & 104268.0333 & 96128.62351 & 0.92193763 \\
\hline Valid N (list wise) & 6 & & & & & \\
\hline
\end{tabular}

(Note: C.V: Coefficient of Variation); Source: Author's own Calculation 


\section{Discussion}

The diagrams Figure 6 and Table 6 show that the mean growth rate of tourist arrival for Leisure/Holiday form of Tourism is highest followed by Medical, Business, Others and Indian Diaspora/VFR. There is a disparity between the growth rate and the coefficient of variation in the data. Although Figure.6 shows that the mean growth rate of tourist arrival for the purpose of Leisure/Holiday form of Tourism is highest but it has also the highest Coefficient of variation (1.108515472). It indicates that this segment has high growth rate but is also highly unstable. Tourist arrival for the purpose of Indian Diaspora/VFR has the lowest Coefficient of variation i.e., (0.689010053) with high stability and rigidity in this segment of tourism but with negative growth rate Figure.6, followed by Business Tourism (o.708091993), Medical Tourism (0.906024472), Other forms of Tourism (o.92193763) and Leisure/Holiday form of Tourism (1.108515472). The highest Coefficient of variation is found in Leisure/Holiday form of Tourism i.e., (1.108515472) which reflects that this segment is highly unstable followed by Other forms of Tourism with the $2^{\text {nd }}$ highest in Coefficient of variation with the value (0.92193763).

\section{Conclusion}

From the above analysis it can be stated that Leisure/Holiday form of Tourism segment has the highest fluctuation followed by Other forms of Tourism segment and Medical form of Tourism Segment. Indian Diaspora/VFR is stable as compared to other three segments but has negative growth rate and so it is lacking in growth.

As these four segments are lacking behind it can be stated that these segments need to be looked after to increase the percentage share as well as to make these segments stable enough so that it may create economic benefits. Certain policy prescriptions may be made in this respect to remove the instability. The Government of India may - (1) Look after the immigration and Visa formalities like extension of E-Visa facilities to Bangladesh as has been granted to other 169 countries. (2) More humane approach towards visa extension and minor violations of rules, without compromising with national security. (3) Visa for the purpose of Medical tourism needs to be more convenient to avoid long queues and pressure of documentation. (4) Liberal approach in respect of Visa to genuine Bangladeshi businessmen especially for the investors. (5) Special consideration in respect of immigration and Visa formalities to Bangladeshi students.

As the tourist inflow in a particular destination is an important factor for tourism and economic development of that country, determining the growth according to segment is also important to trace the lacking so that other countries may follow some of these country specific policies in order to boost their tourism industry.

This research paper has certain limitations and it can act as a reference for future research. Firstly, data regarding revenue generation or tourism receipt by Bangladeshi tourists visiting India in particular are not available. Secondly, the present study is related to segment wise analysis of growth rate and stability considering the variables- Business, Leisure/Holiday, Medical, Indian Diaspora/VFR and Other forms of tourism. But indepth research is necessary to understand the growth rate and stability of revenue generation in these variables in particular which may give us a clear picture of whether there is an economic development through the arrival of Bangladeshi tourists to India or not. 


\section{References}

Aliqah, K.M.A., Al-rfou, A.N. 2010. The Role of Tourism Sector on Economic Development in Jordan during the Period 1990-2008. European Journal of Economics, Finance and Administrative Sciences 18, 173-180.

Annual Report.2017-18. Ministry of Tourism, Government of India. Retrieved on 29th February, 2020 from https://www.tourism.gov.in/.

Balaguer, J., Cantavella- Jorda, M. 2002. Tourism as a Long-Run Economic Growth Factor: The Spanish Case. Applied Economics 34(7), 877-884.

Bulgan, G., Maden, Işık., Yildirim, S. 2019. The Effect of Tourism Sector on Economic Growth: An Empirical Study on Turkey. Journal of Yaşar University 14(55), 215-225. doi: 10.19168/ jyasar.529762

Cárdenas-García, P.J., Rivero, M.S., Pulido-Fernández, J.I. 2013. Does Tourism Growth Influence Economic Development?. Journal of Travel Research 54(2), 206- doi: 221. $10.1177 / 0047287513514297$.

Du, D., Lew, A., Ng, P. 2014. Tourism and Economic Growth. Journal of Travel Research 55(4), 454-464. doi: 10.1177/oo47287514563167.

Ekanayake, E.M, Long, A.E. 2012. Tourism Development and Economic Growth in Developing Countries. International Journal of Business and Finance Research 6(1), 51-63.

Implementation of e-Visa scheme for Tourist, Business and Medical purposes.2017.Bureau of Immigration, Ministry of Home Affairs, Government of India. Retrieved on $29^{\text {th }}$ February, 2020 from https://boi.gov.in/content/implementation-e-visa-scheme-tourist-business-and-medical-purposes-wef-01042017.

India Tourism Statistics Reports.2003-2018. Market Research Division, Ministry of Tourism, Government of India. Retrieved on $\mathrm{O}^{\text {rd }}$ March, 2020 from http://tourism.gov.in/market-research-and-statistics.

Jimenez, I.C., Pulina, M. 2010. Inbound Tourism and long-Run Economic Growth, Current Issues in Tourism 13(1), 61-74, DOI: 10.1080/13683500802684411

Kim, H.J., Chen, M.H., Jang, S. 2006. Tourism Expansion and Economic Development: The Case of Taiwan. Tourism Management 27(5), 925-933. doi:10.1016/j.tourman.2005.05.011.

Lee, C.C., Chang, C.P. 2008. Tourism Development and Economic Growth: A Closer Look at Panels. Tourism Management 29(1), 180-192. doi: 10.1016/j.tourman.2007.02.013.

Ohlan, R. 2017. The Relationship between Tourism, Financial Development and Economic Growth in India. Future Business Journal 3(1), 9-22. doi: 10.1016/j.fbj.2017.01.003.

Open Government Data (OGD) Platform India.2020. Government of India. Retrieved on 29th February, 2020 from https://data.gov.in/catalog/tourism-statistics india?filters\% 5 Bfield catalog reference $\% 5 \mathrm{D}=92149$ \& for mat $=$ json\&offset $=18 \&$ limit $=6 \&$ sort $\% 5$ Bcreated $\% 5 \mathrm{D}=-$ desc.

Rout, H.B., Mishra, P.K., Pradhan, BB. 2016. Trend and Progress of Tourism in India: An Empirical Analysis. International Journal of Economic Research 13(5), 2265-2275.

Sinclair, M.T. 1998. Tourism and Economic Development: A Survey. Journal of Development Studies 34(5), 1-51. doi:10.1080/00220389808422535.

Study on Visit of Nationals of Bangladesh to India. 2018. Ministry of Tourism, Government of India. Retrieved on ${ }^{\text {rd }}{ }^{\text {rd }}$ March, 2020 from http://tourism.gov.in/sites/default/files/Other/ Final\%2oReport\%200n\%2oVisit\%20of\%2oNationals\%20of\%2oBangladesh\%2oto\%2oIndia. pdf. 
Travel and Tourism Economic Impact India. 2018. World Travel \& Tourism Council (WTTC). Retrieved on $29^{\text {th }}$ February, 2020 from https://www.wttc.org/economic-impact/country-analysis/country-reports/.

Witt, S.F., Turner, L.W. 2002. Trends and Forecasts for Inbound Tourism to China. Journal of Travel E Tourism Marketing 13(1-2), 97-107. doi:10.130o/Jo73v13no1_07.

Zurub, H., Ionescu, A., Constantin,V. 2015. Measuring the Economic Impact of Tourism in European Emerging Markets.[Special Issue]. Procedia Economics and Finance 32. doi: 95-102. 10.1016/S2212-5671(15)01369-6.

\section{Appendix}

Table 8. Calculations to Find the Values of Parameters

\begin{tabular}{|c|c|c|c|c|}
\hline Years (x) & FTAs (y) & $t=x-c / d$ & $y t$ & $t^{2}$ \\
\hline 2001 & 431312 & -8 & -3450496 & 64 \\
\hline 2002 & 435867 & -7 & -3051069 & 49 \\
\hline 2003 & 454611 & -6 & -2727666 & 36 \\
\hline 2004 & 477446 & -5 & -2387230 & 25 \\
\hline 2005 & 456371 & -4 & -1825484 & 16 \\
\hline 2006 & 484401 & -3 & -1453203 & 9 \\
\hline 2007 & 480240 & -2 & -960480 & 4 \\
\hline 2008 & 541884 & -1 & -541884 & 1 \\
\hline$C=2009$ & 468899 & 0 & 0 & 0 \\
\hline 2010 & 431962 & 1 & 431962 & 1 \\
\hline 2011 & 463543 & 2 & 927086 & 4 \\
\hline 2012 & 487397 & 3 & 1462191 & 9 \\
\hline 2013 & 524923 & 4 & 2099692 & 16 \\
\hline 2014 & 942562 & 5 & 4712810 & 25 \\
\hline 2015 & 1133879 & 6 & 6803274 & 36 \\
\hline 2016 & 1380409 & 7 & 9662863 & 49 \\
\hline 2017 & 2156557 & 8 & 17252456 & 64 \\
\hline Total & $\Sigma y=11752263$ & $\Sigma \mathrm{t}=0$ & $\sum \mathrm{yt}=26954822$ & $\Sigma \mathrm{t}^{2}=40$ \\
\hline
\end{tabular}

( $C=$ Change of origin i.e., 2009; $d=$ Change of scale i.e., $1 \mathrm{yr}$ ); Source: Researchers Own Calculation

Putting the value of $\Sigma \mathrm{y}, \Sigma \mathrm{t}, \Sigma \mathrm{yt}, \Sigma \mathrm{t}^{2}$ from the above table:

$\mathbf{\Sigma y}=\mathbf{n a}+\mathbf{b} \mathbf{\Sigma t}$

$11752263=17 \mathrm{a}+\mathrm{b} \times \mathrm{o}$

$17 \mathrm{a}=11752263$

$\mathrm{a}=691309.5882$

$\Sigma \mathbf{y t}=\mathbf{a} \Sigma \mathbf{t}+\mathbf{b} \Sigma \mathbf{t}^{2}$

$26954822=a \times 0+b \times 408$

$\mathrm{b}=26954822 / 408$

$b=66065.74 .02$ 
Role of Foreign Tourist Arrivals from Bangladesh

in Indian Tourism Development: A Segment-wise Analysis

Table 9. Calculations to Find the Values of Parameters

\begin{tabular}{|c|c|c|c|c|c|c|c|}
\hline Years (x) & FTAs (y) & $t=x-c / d$ & $y t$ & $t^{2}$ & $y t^{2}$ & $t^{3}$ & $t^{4}$ \\
\hline 2001 & 431312 & -8 & -3450496 & 64 & 27603968 & -512 & 4096 \\
\hline 2002 & 435867 & -7 & -3051069 & 49 & 21357483 & -343 & 2401 \\
\hline 2003 & 454611 & -6 & -2727666 & 36 & 16365996 & -216 & 1296 \\
\hline 2004 & 477446 & -5 & -2387230 & 25 & 11936150 & -125 & 625 \\
\hline 2005 & 456371 & -4 & -1825484 & 16 & 7301936 & -64 & 256 \\
\hline 2006 & 484401 & -3 & -1453203 & 9 & 4359609 & -27 & 81 \\
\hline 2007 & 480240 & -2 & -960480 & 4 & 1920960 & -8 & 16 \\
\hline 2008 & 541884 & -1 & -541884 & 1 & 541884 & -1 & 1 \\
\hline$C=2009$ & 468899 & 0 & 0 & 0 & 0 & 0 & 0 \\
\hline 2010 & 431962 & 1 & 431962 & 1 & 431962 & 1 & 1 \\
\hline 2011 & 463543 & 2 & 927086 & 4 & 1854172 & 8 & 16 \\
\hline 2012 & 487397 & 3 & 1462191 & 9 & 4386573 & 27 & 81 \\
\hline 2013 & 524923 & 4 & 2099692 & 16 & 8398768 & 64 & 256 \\
\hline 2014 & 942562 & 5 & 4712810 & 25 & 23564050 & 125 & 625 \\
\hline 2015 & 1133879 & 6 & 6803274 & 36 & 40819644 & 216 & 1296 \\
\hline 2016 & 1380409 & 7 & 9662863 & 49 & 67640041 & 343 & 2401 \\
\hline 2017 & 2156557 & 8 & 17252456 & 64 & 138019648 & 512 & 4096 \\
\hline Total & $\Sigma y=11752263$ & $\sum \mathrm{t}=0$ & $\begin{array}{c}\sum \mathrm{yt}= \\
26954822\end{array}$ & $\Sigma \mathrm{t}^{2}=408$ & $\begin{array}{c}\sum y t^{2}= \\
376502844\end{array}$ & $\Sigma t^{3}=0$ & $\Sigma t^{4}=17544$ \\
\hline
\end{tabular}

Source: Researchers Own Calculation

Putting the value of $\sum \mathrm{y}, \sum \mathrm{t}, \Sigma \mathrm{t}^{2}, \Sigma \mathrm{t}^{3}, \Sigma \mathrm{t}^{4}, \Sigma \mathrm{yt}, \Sigma \mathrm{t}^{2} \mathrm{y}$ from the above table:

Now putting the value of ' $a$ ' and ' $b$ ' and ' $c$ ' in Trend Equation:

$\Sigma y=\mathbf{n a}+\mathbf{b} \Sigma \mathbf{t}+\mathbf{c} \Sigma \mathbf{t}^{2}$

398899.34 = a

$\Sigma y t=a \Sigma t+b \Sigma t^{2}+c \Sigma t^{3}$

$66065 \cdot 74=b$

$\Sigma \mathbf{t}^{2} \mathbf{y}=\mathbf{a} \Sigma \mathbf{t}^{2}+\mathbf{b} \Sigma \mathbf{t}^{3}+\mathbf{c} \Sigma \mathbf{t}^{4}$

$12183.76=\mathrm{c}$ 